\title{
Coenzyme $B_{12}$ model studies: An HSAB approach to the equilibria and kinetics of axial ligation of alkyl(aquo)- cobaloximes by imidazole and cyanide
}

\author{
VADDEBOINA SRIDHAR and S SATYANARAYANA* \\ Department of Chemistry, Osmania University, Hyderabad 500 007, India \\ e-mail: satya_sirasani@yahoo.com
}

MS received 4 March 2000; revised 9 June 2000

\begin{abstract}
Kinetics and equilibria of the axial ligation of alkyl(aquo)cobaloximes by imidazole and cyanide have been measured spectrophotometrically in aqueous solutions of ionic strength $1.0 \mathrm{M}$ at $25^{\circ} \mathrm{C}$ as a function of $p \mathrm{H}$. Comparison of $K_{\mathrm{IMD}}$ and $K_{\mathrm{CN}^{-}}$of $\mathrm{CH}_{3}, \mathrm{C}_{2} \mathrm{H}_{5}$ and $\mathrm{BrCH}_{2}$ cobaloximes indicates that their stability is in the order $\mathrm{BrCH}_{2}>\mathrm{CH}_{3}>\mathrm{C}_{2} \mathrm{H}_{5}$. As the electron-withdrawing capacity of the alkyl group trans to water increases, the electron density of the cobalt(III) decreases and thus it becomes a stronger Lewis acid and binds more strongly to imidazole and cyanide. The association and dissociation rate constants are better correlated to the relative softness of the ligand showing that cyanide binds 30 times faster than imidazole. These complexes are isolated and are characterized by IR and ${ }^{1} \mathrm{H}$ NMR spectra.
\end{abstract}

Keywords. Alkyl cobaloximes; association constants; hand and soft acids and bases; rhodoximes; dissociation constants.

\section{Introduction}

Vitamin $\mathrm{B}_{12}$ coenzyme as well as methyl cobalamines are octahedral $\mathrm{Co}(\mathrm{III})$ compounds containing direct $\mathrm{Co}-\mathrm{C}$ bond which occupy an axial coordination position relative to a corrinoid ring system ${ }^{1,2}$. The cobaloximes $\mathrm{RCo}(\mathrm{DH})_{2} \mathrm{OH}_{2}$ (where $\mathrm{DH}=$ mono anion of dimethyl glyoxime) are often studied as models for cobaloximes and the alkyl complexes have been the subject of extensive kinetic mechanistic studies ${ }^{3-9}$. The activity has been motivated by the possibility that axial base release may be involved in biological mechanisms. One of the principal advantages in investigating, is the solubility of these compounds in non-coordinating solvents. Under such conditions, it is possible to observe the substitution process uncomplicated by the intermediacy of solvato complexes ${ }^{10}$.

The ligand substitution reaction of vitamin $\mathrm{B}_{12}$, and its derivatives ${ }^{11-15}$ and $\mathrm{B}_{12}$ model compounds, the cobaloximes ${ }^{16,17}$, are of interest from the point of view of the mechanisms of inorganic ligand substitution reactions and the possibility that such reactions may play an important role in coenzyme $\mathrm{B}_{12}$ catalysed reactions. Such ligation changes may indeed be important in enzymatic reactions involving $\mathrm{B}_{12}{ }^{18-25}$. Randaccio et $a l^{26-28}$ studied the structural and solution properties of rhodoximes, compared the cobaloximes and rhodoximes and discussed the basis of electronic and steric effects.

*For correspondence 
These studies have furnished a foundation for understanding the mechanism of the $\mathrm{Co}-\mathrm{C}$ bond cleavage in the vitamin $\mathrm{B}_{12}$ coenzyme. Marques et al ${ }^{29}$ and Randaccio et al ${ }^{30,31}$ studied the molecular mechanism of modelling of the cobaloximes. Variation of the rate constants for the alkylation of tributylphosphono cobaloxime by some alkylchlorides is explained using the Taft equation ${ }^{32}$. Mixed ligand complexes of $\left[\mathrm{CNCo}(\mathrm{DH})_{2} \mathrm{~L}\right]^{-}$ $(\mathrm{L}=$ imidazole primaryamines, pyridine etc. $)$ are prepared ${ }^{32-35}$. Based on the changes in the $v \mathrm{CN}$ and ${ }^{13} \mathrm{C}$ and ${ }^{15} \mathrm{~N}$ chemical shifts with the basicity of trans axial ligand, we expect that $\mathrm{Co}$ to $\mathrm{CN} \pi$ bonding is important in these cyano (ligand) complexes.

We have used imidazole, since imidazole rings (nucleic acid, proteins, antibiotics and cofactors) are present in biological systems playing significant roles in acid/base chemistry, catalysis, H-bonding and metal complexation ${ }^{36}$. Here we report the ligation reactions of imidazole or cyanide with bromomethyl, methyl and ethyl aquocobaloximes.

$$
\mathrm{RCo}(\mathrm{DH})_{2} \mathrm{H}_{2} \mathrm{O}+\mathrm{L} \underset{k_{\text {off }}}{\stackrel{k_{\text {on }}}{\rightleftarrows}} \mathrm{RCo}(\mathrm{DH})_{2} \mathrm{~L}+\mathrm{H}_{2} \mathrm{O},
$$

where $\mathrm{R}=\mathrm{CH}_{3}, \mathrm{C}_{2} \mathrm{H}_{5}$ or $\mathrm{BrCH}_{2}, \mathrm{~L}=$ imidazole, cyanide.

In this work we have taken biologically relevant ligands in an attempt to evaluate the extent of metal to ligand $\pi$ donation in the metal-ligand bond as a basis for studies on the kinetic trans effect on the alkyl cobalt complexes.

\section{Materials and methods}

Alkyl halides (Sigma), buffer salts, $\mathrm{KCl}$ and solvents (BDH) of the highest commercially available purity were used without further purification. Doubly distilled water was used throughout. The $\mathrm{RCo}(\mathrm{DH})_{2} \mathrm{OH}_{2}$ complex $\left(\mathrm{R}=\mathrm{CH}_{3}, \mathrm{C}_{2} \mathrm{H}_{5}\right.$ or $\left.\mathrm{BrCH}_{2}\right)$ was synthesized directly from dimethyl glyoximes, cobaltous acetate and $\mathrm{CH}_{3} \mathrm{Br}, \mathrm{C}_{2} \mathrm{H}_{5} \mathrm{Br}$ or $\mathrm{CH}_{2} \mathrm{Br}_{2}$ as described previously ${ }^{37}$. The complexes were characterized by ${ }^{13} \mathrm{C}$ and ${ }^{1} \mathrm{H}$ NMR spectra.

$\mathrm{BrCH}_{2} \mathrm{Co}(\mathrm{DH})_{2} \mathrm{IMD}\left(\mathrm{IMD}=\right.$ Imidazole) complex $^{38,39}$ was prepared by suspending $200 \mathrm{mg}(0.50 \mathrm{mM})$ of $\mathrm{BrCH}_{2} \mathrm{Co}(\mathrm{DH})_{2} \mathrm{OH}_{2}$ in $50 \mathrm{ml}$ of methanol and treated with $50 \mathrm{mg}$ $(0.86 \mathrm{mM})$ of imidazole. The resulting golden yellow solution was stirred at room temperature for $6 \mathrm{~h}$. The methanol was removed under reduced pressure and water was added to induce precipitation as a yellow powder. The product was recrystallized from methanol, water, washed with water, ethanol and ether and dried in vacuo.

Proton NMR and ${ }^{13} \mathrm{C}$ NMR spectra were recorded on a Varian Gemini $200 \mathrm{MHz}$ NMR spectrometer. Samples were prepared by dissolving $30 \mathrm{mg}$ of $\mathrm{BrCH}_{2} \mathrm{Co}(\mathrm{DH})_{2} \mathrm{OH}_{2}$ or $\mathrm{BrCH}_{2} \mathrm{Co}(\mathrm{DH})_{2} \mathrm{IMD}$ in DMSO- $d_{6}$. Proton and ${ }^{13} \mathrm{C}$ NMR spectra were referred to external standard TSP in DMSO- $d_{6}$. Infrared spectra were obtained on a Perkin-Elmer FTIR-1605 spectrometer using KBr pellets.

Electronic spectra were recorded on a UV-1601 PC spectrometer and single wavelength measurements were made on Elico single beam spectrophotometer SL 171 model. The sample compartment of which was thermostated at $25 \pm 0 \cdot 1^{\circ} \mathrm{C}$. Apparent formation constants for the $\mathrm{RCo}(\mathrm{DH})_{2} \mathrm{IMD}$ complexes were determined spectrophotometrically as described previously ${ }^{40,41}$. Complex formation was monitored at visible wavelength $436-455 \mathrm{~nm}$ depending on the alkyl group. Cobaloxime concentration used was $1.25 \times 10^{-3} \mathrm{M}$ in visible wavelength range in $1.0 \mathrm{~cm}$ path-length cells. Samples containing $\mathrm{KCN}$ or imidazole at various concentration were prepared. $\mathrm{HCl}$, chloroacetic 
acid, formate, acetate, phosphate or tris buffer $(0 \cdot 2 \mathrm{M})$ as needed, to maintain $p \mathrm{H}(1 \cdot 0$ to 9.0) and $\mathrm{KCl}$ (ionic strength $1.0 \mathrm{M}$ ) were used. Samples were incubated at $25^{\circ} \mathrm{C} \pm 0 \cdot 1{ }^{\circ} \mathrm{C}$ until equilibrium was reached as determined by the cessation of absorbance changes. The $p \mathrm{H}$ of the sample was measured after completion of the absorbance measurements, using a Digisum $p \mathrm{H}$-meter equipped with a combined glass electrode. Formation constants were determined from the absorbance data as described previously ${ }^{37,42}$.

\section{Results and discussions}

The IR spectra of $\mathrm{BrCH}_{2} \mathrm{Co}(\mathrm{DH})_{2} \mathrm{OH}_{2}$ shows a broad peak at $3130 \mathrm{~cm}^{-1}$. The absence of a broad peak at $3130 \mathrm{~cm}^{-1}$ in $\mathrm{BrCH}_{2} \mathrm{Co}(\mathrm{DH})_{2} \mathrm{IMD}$ indicates that water is replaced by imidazole. Appearance of a peak at $430 \mathrm{~cm}^{-1}$ indicates that imidazole is coordinated to cobalt through $\mathrm{N}$. The peak at $514 \mathrm{~cm}^{-1}$ is due to the coordination of $\mathrm{C}=\mathrm{N}$ to $\mathrm{Co}$ (III). Peak shifts due to $(\mathrm{C}=\mathrm{C})$ and $(\mathrm{C}=\mathrm{N})$ frequencies of the complex in the region 1450$1650 \mathrm{~cm}^{-1}$ indicates that at least one of the ring nitrogen of imidazole is involved in metal ion coordination. The low intensity band at $2360 \mathrm{~cm}^{-1}$ is due to intramolecular hydrogen bonding in the parent complex $\mathrm{RCo}(\mathrm{DH})_{2} \mathrm{IMD}$.

Imidazole exhibits the following ${ }^{1} \mathrm{H}$ NMR signals, $\mathrm{C} 2-\mathrm{H}(7 \cdot 3 \delta), \mathrm{C} 4-\mathrm{H}(6.75 \delta)$ and $\mathrm{C} 5-\mathrm{H}(6.75 \delta)$ and $\mathrm{N}-\mathrm{H}(12.93 \delta)$. These signals upon coordination to metal ion are shifted downfield (C2-H 7.42 $\delta$, C4-H 7.24 $\delta$, C5-H 6.97 $\delta$ ). Upon coordination the equivalence of protons $\mathrm{C} 4-\mathrm{H}$ and $\mathrm{C} 5-\mathrm{H}$ of imidazole at $6.75 \delta$ is lost and separate signals are obtained downfield. In addition, there is a signal at $2.07 \mathrm{ppm}$ corresponding to 4 equatorial methyls and signal at $3.37 \mathrm{ppm}$ to $\mathrm{BrCH}_{2}$.

The molar conductivity of $\sim 10^{-3} \mathrm{M}$ solutions of the complexes in methanol show that they are non-electrolytes.

\subsection{Spectrophotometric determination of equilibrium constants $\left(K_{f}\right)$ for ligation - Formation constants for the alkyl (IMD) cobaloxime}

Apparent equilibrium constants $K_{f}^{\text {app }}$ for the formation of alkyl cobaloxime adduct from $\mathrm{RCo}\left(\mathrm{D}_{2} \mathrm{H}_{2}\right) \mathrm{OH}_{2}$ and ligand $\mathrm{L}$ from (2), where $(\mathrm{L})_{\text {free }}$ is the equilibrium ligand concentration were determined by spectrophotometric measurements of solution of $\mathrm{RCo}\left(\mathrm{D}_{2} \mathrm{H}_{2}\right) \mathrm{OH}_{2}\left(1.25 \times 10^{-3} \mathrm{M}\right)$ at varying ligand concentrations at $435-455 \mathrm{~nm}$. The data at a given $p \mathrm{H}$ were analysed with a computer by using linear regression based on (3). Figure 1 shows the concentration dependence binding of imidazole to $\mathrm{C}_{2} \mathrm{H}_{5} \mathrm{Co}(\mathrm{DH})_{2} \mathrm{OH}_{2}$. As the concentration of imidazole increases the absorbance decreases,

$$
\begin{aligned}
& K_{f}^{\mathrm{app}}\left[\mathrm{RCo}(\mathrm{DH})_{2} \mathrm{~L}\right] /\left[\mathrm{RCo}(\mathrm{DH})_{2} \mathrm{OH}_{2}\right][\mathrm{L}]_{\text {free }}, \\
& A=A_{0}-\left(\Delta \varepsilon\left[\mathrm{RCo}(\mathrm{DH})_{2} \mathrm{OH}_{2}\right][\mathrm{L}]_{\text {free }}+1 / K_{f}^{\mathrm{app}}\right),
\end{aligned}
$$

where $A_{0}$ is the absorbance of $\mathrm{RCo}(\mathrm{DH})_{2} \mathrm{OH}_{2}$ in the absence of added ligand. $\Delta \varepsilon$ is the difference between the molar absorptivity of $\mathrm{RCo}(\mathrm{DH})_{2} \mathrm{OH}_{2}$ and $\mathrm{RCo}(\mathrm{DH})_{2} \mathrm{~L}$ at the wavelength used and $\left[\mathrm{RCo}(\mathrm{DH})_{2} \mathrm{OH}_{2}\right]$ is the total concentration of cobalt containing species. $K_{f}^{\text {app }}$ values were determined at $p \mathrm{H} 8.0$ to 4.0 for imidazole. The anticipated dependence of $K_{\mathrm{imd}}^{\text {app }}$ was demonstrated for all complexes as shown in figure 2. Slopes of 


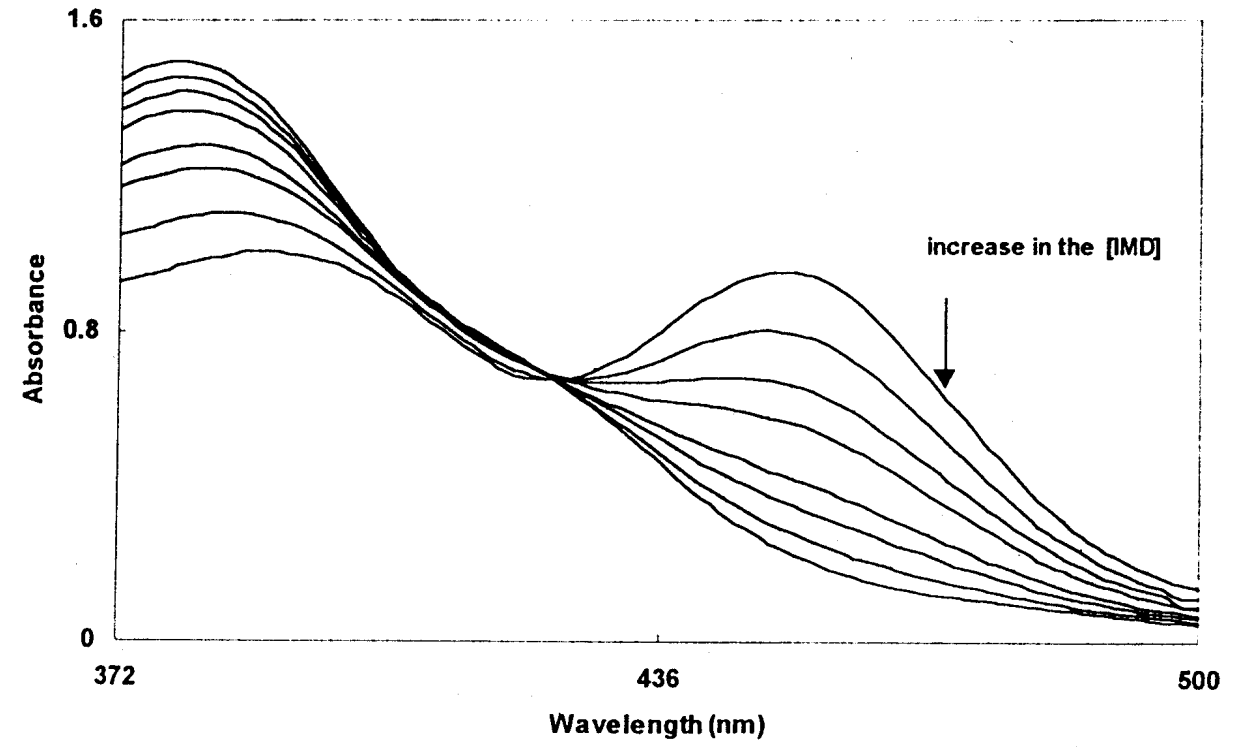

Figure 1. Binding of $\mathrm{C}_{2} \mathrm{H}_{5} \mathrm{Co}(\mathrm{DH})_{2} \mathrm{OH}_{2}$ with varying concentrations of imidazole at $p \mathrm{H}=6.5$ and $25^{\circ} \mathrm{C}$.

the plots of $\log K_{\text {imd }}^{\text {app }}$ vs $p \mathrm{H}$ varied from 0.97 to 0.998 . Values of $K_{\text {imd }}$ were determined from each measurement as,

$$
K_{\mathrm{IMD}}=K_{\mathrm{IMD}}^{\mathrm{app}} / \alpha_{\mathrm{IMD}}
$$

where $\alpha_{\mathrm{IMD}}$ is the fraction of imidazole present as free base calculated using $p K a=7 \cdot 241$ at $25^{\circ} \mathrm{C}$ for imidazole as

$$
\alpha_{\mathrm{IMD}}=K_{a} /\left(K_{a}+\left[\mathrm{H}^{+}\right]\right) .
$$

Values of $K_{\mathrm{IMD}}$ thus determined were independent of measurement of wavelength and complex concentration. A minimum of five values of $K_{\mathrm{IMD}}$ were determined for each complex and averaged to provide the $K_{\mathrm{IMD}}$. Figure 3 shows the $p \mathrm{H}$ dependence of binding of imidazole. Keeping the cobaloxime and ligand concentration constant, spectra were recorded at different $p \mathrm{H}$, and clearly show that as the $p \mathrm{H}$ is increased, binding of imidazole to $\mathrm{BrCH}_{2} \mathrm{Co}(\mathrm{DH})_{2} \mathrm{OH}_{2}$ increases.

\subsection{Formation constants for the alkyl(cyano)cobaloximes}

Apparent formation constants for the $\left[\mathrm{BrCH}_{2} \mathrm{Co}(\mathrm{DH})_{2} \mathrm{CN}^{-}\right]$were calculated as

$$
K_{\mathrm{CN}}^{\mathrm{app}}=\left[\mathrm{RCo}(\mathrm{DH})_{2} \mathrm{CN}^{-}\right] /\left[\mathrm{RCo}(\mathrm{DH})_{2} \mathrm{OH}_{2}\right]\left[\mathrm{CN}^{-}\right]_{T},
$$

where $\left[\mathrm{CN}^{-}\right]_{T}$ is the total ligand concentration of cyanide species (i.e. $\left[\mathrm{CN}^{-}\right]_{T}=\left[\mathrm{CN}^{-}\right]+$ $[\mathrm{HCN}]), K_{\mathrm{CN}}^{\text {app }}$ values are $p \mathrm{H}$ dependent, in general, due to the ionization of HCN ( $p K a$ of $\mathrm{HCN}$ at $25^{\circ} \mathrm{C}=9 \cdot 04$ ), from the equilibria in scheme 1 below and the law of mass action. 


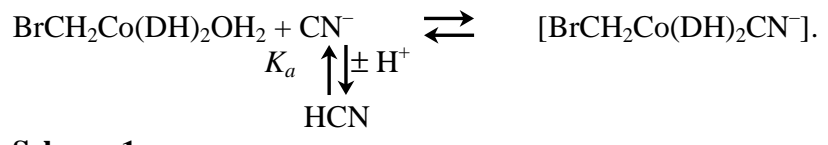

Scheme 1.

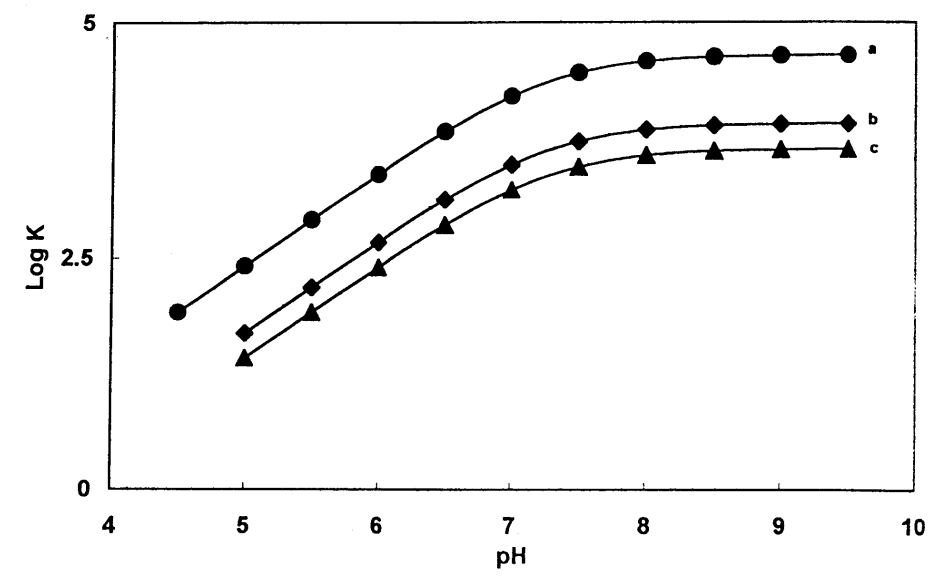

Figure 2. Dependence of $\log \mathrm{K}$ on $\mathrm{pH}$ for the formation of $\mathrm{BrCH}_{2} \mathrm{Co}(\mathrm{DH})_{2} \mathrm{IMD}$ (a), $\mathrm{CH}_{3} \mathrm{Co}(\mathrm{DH})_{2} \mathrm{IMD}(\mathbf{b})$, and $\mathrm{C}_{2} \mathrm{H}_{5} \mathrm{Co}(\mathrm{DH})_{2} \mathrm{IMD}(\mathbf{c})$ at $25^{\circ} \mathrm{C}$.

The dependence of $K_{\mathrm{CN}}^{\mathrm{app}}$ on $\mathrm{H}^{+}$concentration may be readily derived as

$$
K_{\mathrm{CN}}^{\mathrm{app}}=K_{a} K_{\mathrm{CN}} /\left(\left[\mathrm{H}^{+}\right]+K_{a}\right)
$$

Since $K_{\mathrm{CN}}$ values are quite large only the limiting behaviour for $\left[\mathrm{H}^{+}\right] \gg K_{a}$ could be observed,

$$
\lim _{\left[\mathrm{H}^{+}\right]>>K_{a}} K_{\mathrm{CNp}}^{\mathrm{app}}=K_{a}^{*} K_{\mathrm{CN}} /\left[\mathrm{H}^{+}\right] .
$$

The $p \mathrm{H}$ independent behaviour for $\left[\mathrm{H}^{+}\right] \ll K_{a}$ could be demonstrated when

$$
\lim _{\left[\mathrm{H}^{+}\right] \rightarrow 0} K_{\mathrm{CN}}^{\mathrm{app}}=K_{\mathrm{CN}} .
$$

Thus for each measurement of $K_{\mathrm{CN}}^{\mathrm{app}}$, a value of $K_{\mathrm{CN}}$ could be calculated from (7) using the measured $p \mathrm{H}$ and $K_{a}$ for $\mathrm{HCN}$ and these values were averaged to obtain the estimation of $\mathrm{KCN}$ summarized in table 1 . The failure to observe any positive deviation of $K_{\mathrm{CN}}^{\text {app }}$ from the strictly linear decrease with $p \mathrm{H}$ for $\mathrm{BrCH}_{2} \mathrm{Co}(\mathrm{DH})_{2} \mathrm{OH}_{2}$ suggests that any binding of HCN itself must be quite weak indeed. 


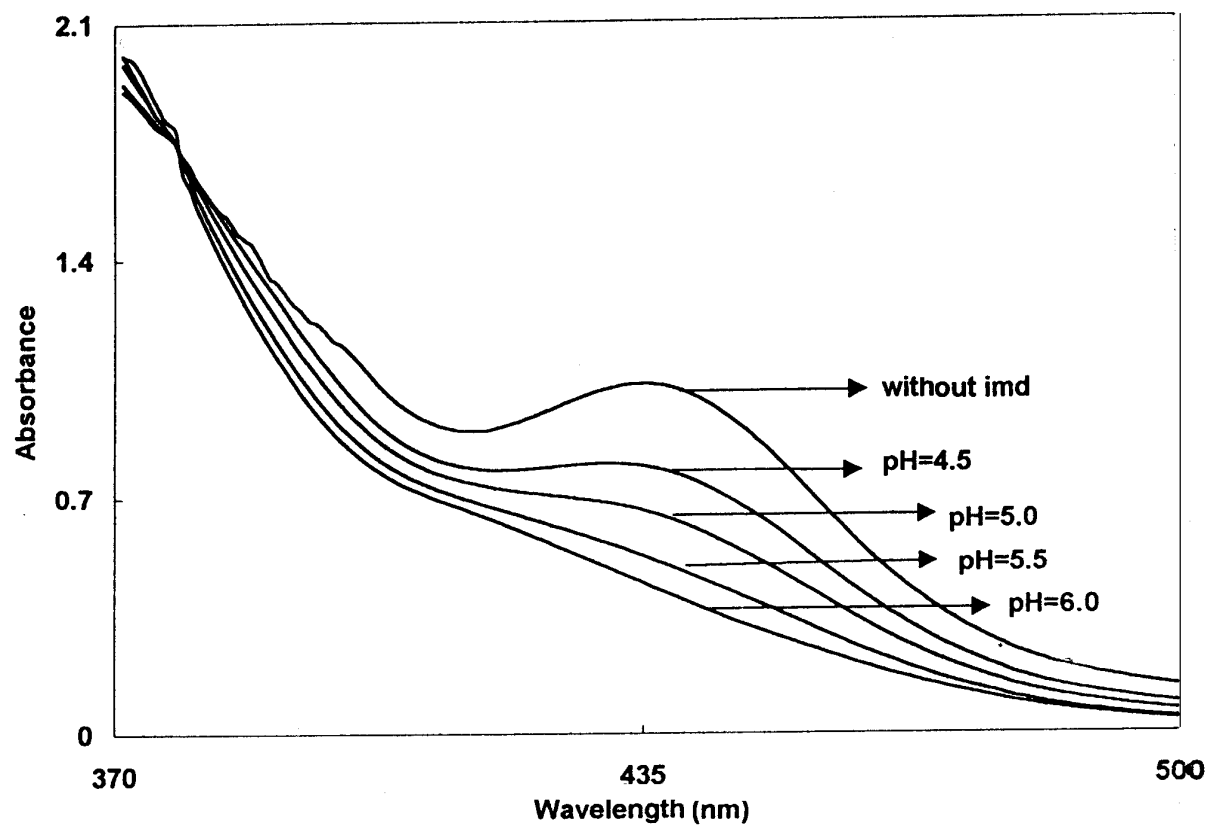

Figure 3. Dependence of $p \mathrm{H}$ on the binding of $\mathrm{BrCH}_{2} \mathrm{Co}(\mathrm{DH})_{2} \mathrm{OH}_{2}$ with $4.3 \times$ $10^{-3} \mathrm{M}$ imidazole at $25^{\circ} \mathrm{C}$.

Table 1. Formation constants for $\mathrm{RCo}(\mathrm{DH})_{2} \mathrm{IMD}$ and $\left[\mathrm{RCo}(\mathrm{DH})_{2} \mathrm{CN}^{-}\right]$.

\begin{tabular}{|c|c|c|c|c|c|c|c|c|c|c|c|c|c|c|}
\hline \multirow[b]{2}{*}{$(\mathrm{R}=)$} & \multirow[b]{2}{*}{$K_{\mathrm{IMD}}$} & \multirow[b]{2}{*}{$* K_{\mathrm{CN}}$} & \multirow{2}{*}{$\begin{array}{l}K_{\mathrm{CN}} / \\
K_{\mathrm{IMD}}\end{array}$} & \multicolumn{11}{|c|}{$\log K_{\mathrm{IMD}}^{\mathrm{app}}$ values at different $p \mathrm{H}$ values } \\
\hline & & & & $4 \cdot 5$ & $5 \cdot 0$ & $5 \cdot 5$ & $6 \cdot 0$ & $6 \cdot 5$ & $7 \cdot 0$ & $7 \cdot 5$ & $8 \cdot 0$ & 8.5 & 9.0 & $9 \cdot 5$ \\
\hline $\mathrm{BrCH}_{2}$ & 47334 & $12.8 \times 10^{8}$ & 27036 & $1 \cdot 91$ & $2 \cdot 41$ & $2 \cdot 90$ & $3 \cdot 39$ & $3 \cdot 84$ & $4 \cdot 21$ & $4 \cdot 46$ & $4 \cdot 58$ & 4.63 & $4 \cdot 65$ & $4 \cdot 65$ \\
\hline $\mathrm{CH}_{3}$ & 8512 & $1.06 \times 10^{8}$ & 12400 & - & $1 \cdot 68$ & $2 \cdot 18$ & $2 \cdot 66$ & $3 \cdot 11$ & $3 \cdot 49$ & $3 \cdot 73$ & $3 \cdot 86$ & $3 \cdot 90$ & $3 \cdot 92$ & $3 \cdot 92$ \\
\hline $\mathrm{C}_{2} \mathrm{H}_{5}$ & 4580 & $4.7 \times 10^{\prime}$ & 10300 & - & $1 \cdot 41$ & $1 \cdot 91$ & $2 \cdot 39$ & $2 \cdot 84$ & $3 \cdot 22$ & $3 \cdot 47$ & $3 \cdot 59$ & 3.63 & $3 \cdot 65$ & $3 \cdot 65$ \\
\hline
\end{tabular}

*ref. [37]

\subsection{Direct determination of ligation rates $\left(k_{\text {on }}\right)$}

For the imidazole and cyanide, the second-order rate constant for ligation to $\mathrm{BrCH}_{2} \mathrm{Co}(\mathrm{DH})_{2} \mathrm{OH}_{2}$ was determined from absorbance measurements at $436 \mathrm{~nm}$ obtained under pseudo-first-order conditions with ligand concentration in atleast tenfold excess over $\mathrm{BrCH}_{2} \mathrm{Co}(\mathrm{DH})_{2} \mathrm{OH}_{2}$ concentration. The $\mathrm{pH}$ was maintained at 4.5 with $\mathrm{CH}_{3} \mathrm{COOH}-$ $\mathrm{CH}_{3} \mathrm{COONa}$ buffer in case of imidazole, whereas in case of $\mathrm{CN}^{-} p \mathrm{H} 2.0$ was maintained with $\mathrm{KH}_{2} \mathrm{PO}_{4}-\mathrm{H}_{3} \mathrm{PO}_{4}$. The reactions were initiated by adding a small volume of $\mathrm{BrCH}_{2} \mathrm{Co}(\mathrm{DH})_{2} \mathrm{OH}_{2}$ solution in $25 \%$ methanol to cuvettes containing buffer, $\mathrm{KCl}$ and ligand to the thermostated cell compartment of a UV 1601PC spectrometer maintained at $25 \cdot 0 \pm 0 \cdot 1{ }^{\circ} \mathrm{C}$. Figure 4 shows the time-dependent binding of imidazole to $\mathrm{BrCH}_{2} \mathrm{Co}(\mathrm{DH})_{2} \mathrm{OH}_{2}$ at $p \mathrm{H}$ 6.0. First-order rate constants $\left(k_{\mathrm{obs}}\right)$ were obtained by the 
method previously described ${ }^{43}$. Second-order rate constants $k_{\|(\text {obs })}$ for ligation were obtained from the slopes of graphs of $k_{\mathrm{obs}}$ vs ligand concentration. Significant ordinate intercepts on such plots $\left(k_{\text {off }}\right)$, were generally too small to be accurately determined,

$$
k_{\mathrm{obs}}=k_{\mathrm{on}}^{\mathrm{app}}[\mathrm{L}]_{\mathrm{total}}+k_{\mathrm{off}}
$$

Non-zero ordinate intercepts of such plots when present gave values for the reverse rate constant $k_{\text {off }}$ according to

$$
k_{\mathrm{obs}}=k_{f}[\mathrm{~L}]+k_{-f}
$$

In this measurement of $k_{\mathrm{on}}$ the plots of $k_{\mathrm{obs}}$ Vs [IMD] showed no significant deviation from linearity at increasing IMD concentration (up to 1:35 ratio). It is observed that at $p \mathrm{H}$ $4 \cdot 5$, as the concentration of ligand increases the rate of formation of complex $k_{f}$ also increases (figure 5).

In case of cyanide at $p \mathrm{H} 2 \cdot 0$, as the concentration of cyanide increases, the rate of formation of complex increases (figure 6). In case of cyanide binding to $\mathrm{BrCH}_{2} \mathrm{Co}(\mathrm{DH})_{2} \mathrm{OH}_{2}$ initially $(1$ to $2 p \mathrm{H})$ as $p \mathrm{H}$ increases the rate increases then remains constant even the $p \mathrm{H}$ increases to 6.0 (figure 7).

Rate constant for ligand dissociation from $\left[\mathrm{BrCH}_{2} \mathrm{Co}(\mathrm{DH})_{2} \mathrm{IMD}\right]$ (figure 8) or $\left[\mathrm{BrCH}_{2} \mathrm{Co}(\mathrm{DH})_{2} \mathrm{CN}\right]^{-}$were also obtained from the change in absorbance at suitable wavelength of a solution of $\mathrm{BrCH}_{2} \mathrm{Co}(\mathrm{DH})_{2} \mathrm{IMD}$ or $\mathrm{CN}^{-}$(generated in situ).

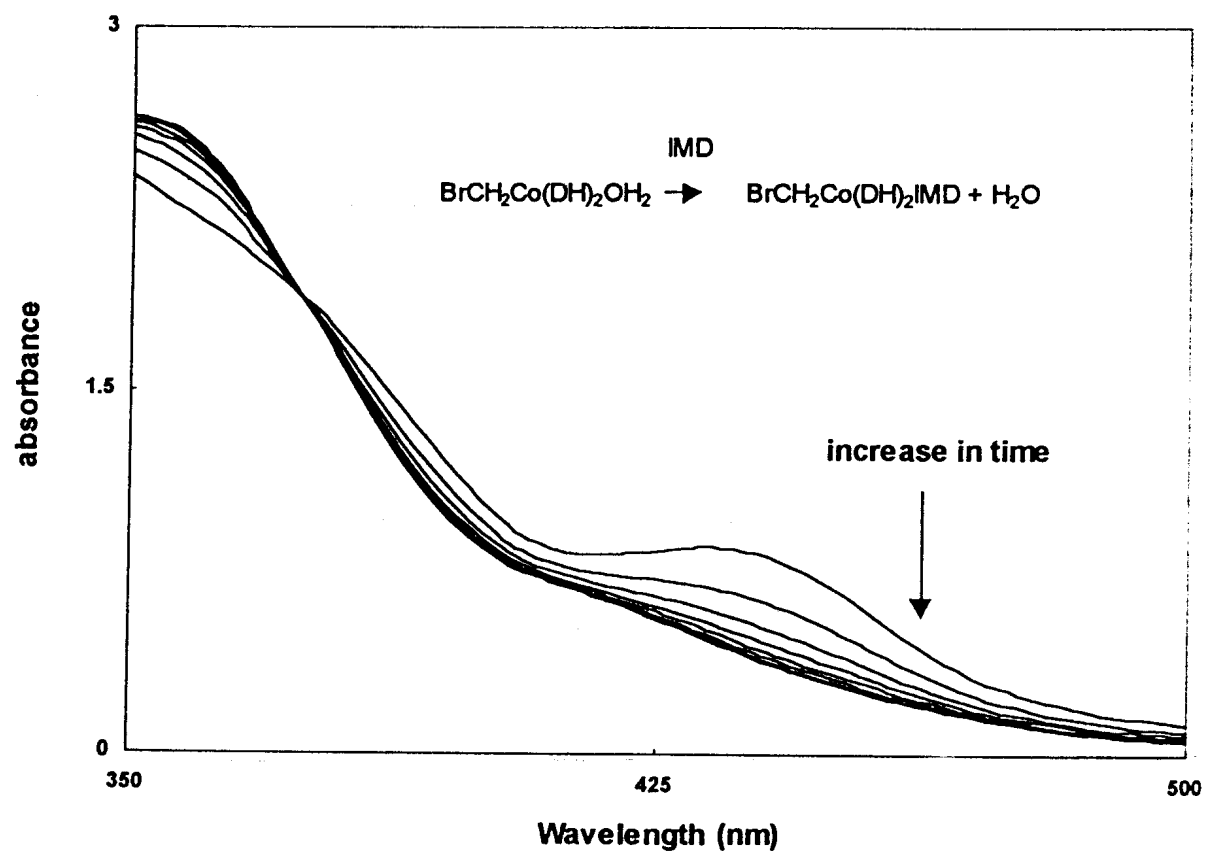

Figure 4. Kinetics of association of $\mathrm{BrCH}_{2} \mathrm{Co}(\mathrm{DH})_{2} \mathrm{OH}_{2}$ with IMD at $p \mathrm{H}=6 \cdot 0$ and $25^{\circ} \mathrm{C}$. 


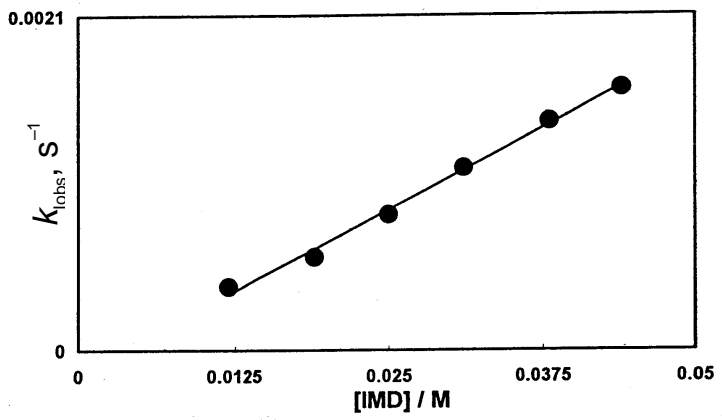

Figure 5. Dependence of [IMD] on the pseudo first-order rate constants, $k_{\mathrm{obs}}$, for the formation of $\mathrm{BrCH}_{2}(\mathrm{DH})_{2} \mathrm{IMD}$ at $p \mathrm{H} 4.5$ and $25^{\circ} \mathrm{C}$, the gradient $k_{\|}=4.04 \times$ $10^{-2} \mathrm{dm}^{3} \mathrm{~mol}^{-1} \mathrm{~s}^{-1}$.

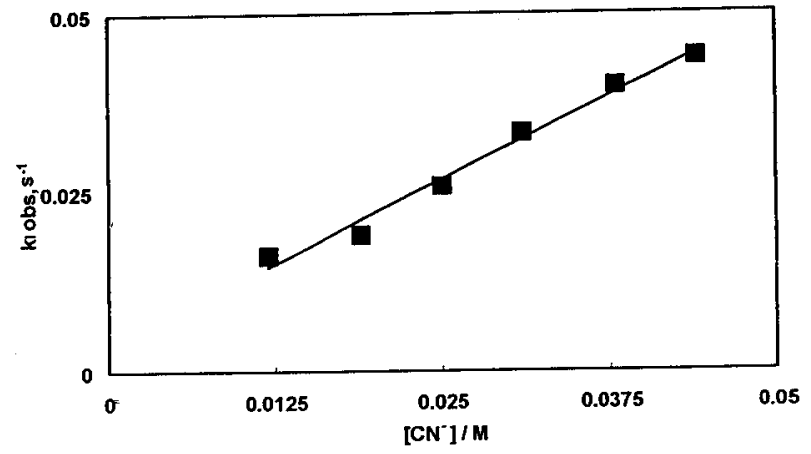

Figure 6. Dependence of $\left[\mathrm{CN}^{-}\right]$on the pseudo first-order rate constants, $k_{\mathrm{obs}}$, for the formation of $\left[\mathrm{BrCH}_{2} \mathrm{Co}(\mathrm{DH})_{2} \mathrm{CN}^{-}\right]$at $p \mathrm{H} 2.0$ and $25^{\circ} \mathrm{C}$, the gradient $k_{\|}=9.35 \times$ $10^{-2} \mathrm{dm}^{3} \mathrm{~mol}^{-1} \mathrm{~s}^{-1}$.

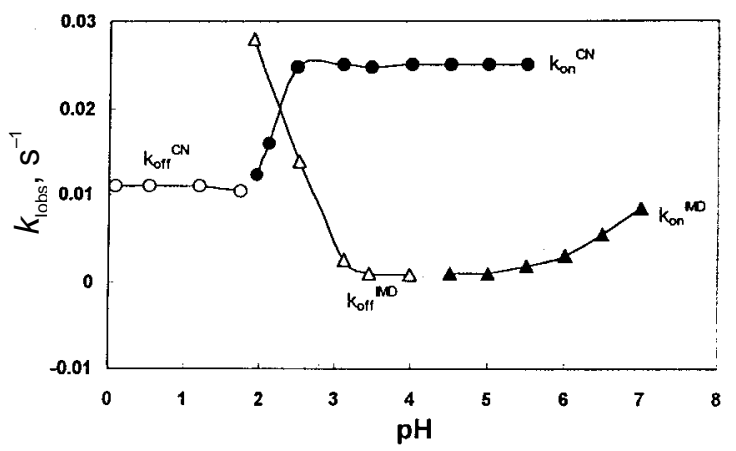

Figure 7. Comparative dependence of $p \mathrm{H}$ on pseudo first-order rate constants, $k_{\text {on }}$ (association), and $k_{\text {off }}$ (dissociation) for $\mathrm{BrCH}_{2} \mathrm{Co}(\mathrm{DH})_{2} \mathrm{IMD}$ and $\left[\mathrm{BrCH}_{2} \mathrm{Co}\right.$ $\left.(\mathrm{DH})_{2} \mathrm{CN}^{-}\right]$. 


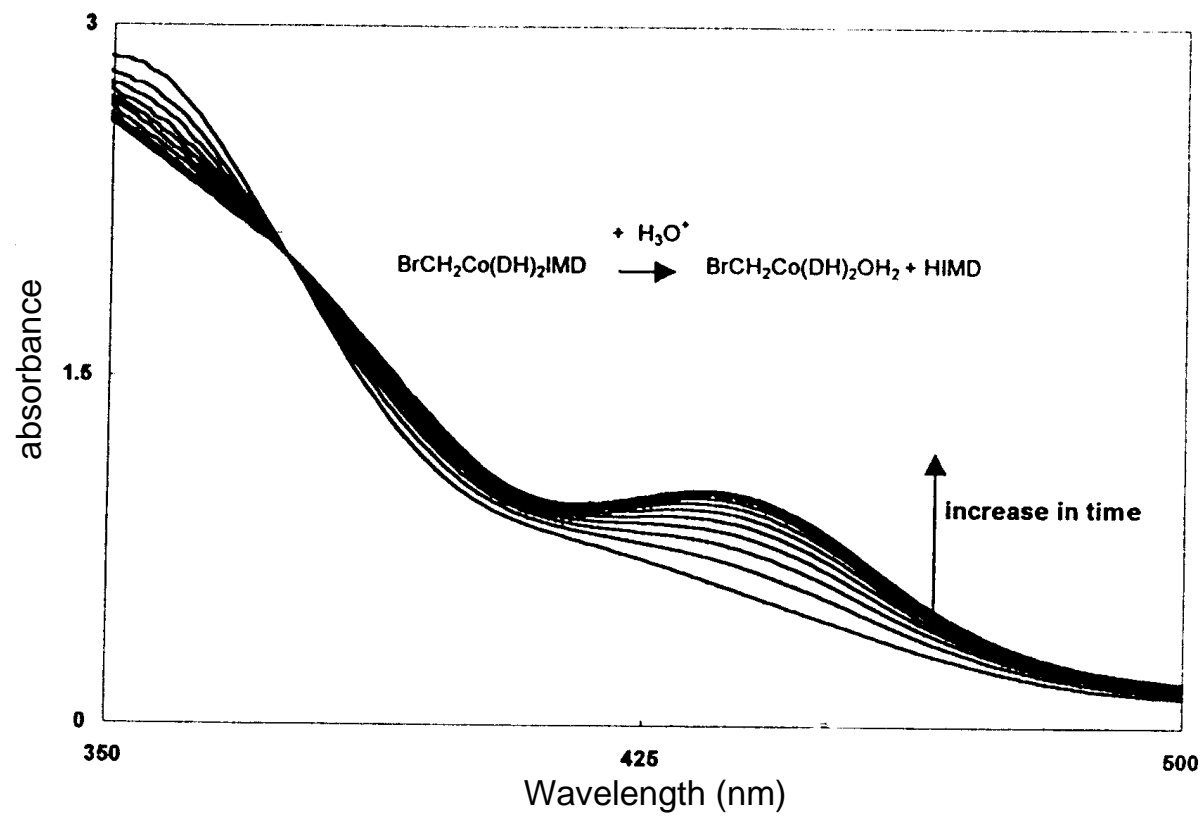

Figure 8. Dissociation kinetics of $\mathrm{BrCH}_{2} \mathrm{Co}(\mathrm{DH})_{2} \mathrm{IMD}$ into $\mathrm{BrCH}_{2} \mathrm{Co}(\mathrm{DH})_{2} \mathrm{OH}_{2}$ at $p \mathrm{H}=3.0$ and $25^{\circ} \mathrm{C}$.

\subsection{Evidence for axial ligation by IMD or $C N$}

Evidence for axial ligation has been obtained from cyclic reaction in which the regeneration of $\mathrm{BrCH}_{2} \mathrm{Co}(\mathrm{DH})_{2} \mathrm{OH}_{2}$ was demonstrated spectrophotometrically in dissociation kinetic experiments. As the $p \mathrm{H}$ is lowered all the imidazole bound to cobaloxime is taken out and aquo complex regenerated.

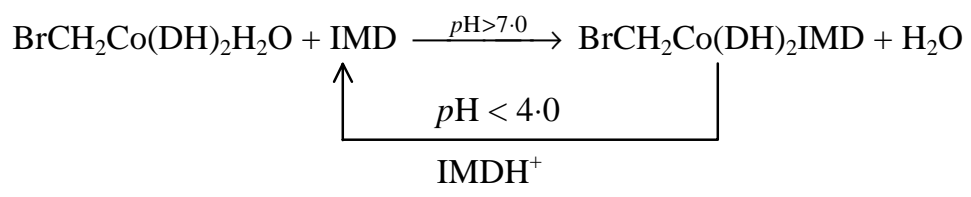

The ligation reaction of $\mathrm{BrCH}_{2} \mathrm{Co}(\mathrm{DH})_{2} \mathrm{OH}_{2}$ in excess ligand is first-order with respect to $\mathrm{BrCH}_{2} \mathrm{Co}(\mathrm{DH})_{2} \mathrm{OH}_{2}$ concentration. No buffer catalysis is observed with phosphate and acetate buffer concentration up to $0.5 \mathrm{M}$. Plots of pseudo-first-order rate constants $\left(k_{\mathrm{obs}}\right)$ for ligation with $\mathrm{BrCH}_{2} \mathrm{Co}(\mathrm{DH})_{2} \mathrm{OH}_{2}$ vs concentration of imidazole at $p \mathrm{H} 4.5$ are linear up to $0.05 \mathrm{M}$ (IMD) and indicate that the reactions are also first order with respect to ligand concentration.

Rate of association of imidazole to $\mathrm{BrCH}_{2} \mathrm{Co}(\mathrm{DH})_{2} \mathrm{OH}_{2}$ gives simple monophasic kinetics and plots of $k_{\mathrm{obs}}$ against ligand concentration are linear with intercepts not significantly different from zero. The kinetics of ligand addition to $\mathrm{BrCH}_{2} \mathrm{Co}(\mathrm{DH})_{2} \mathrm{OH}_{2}$ is strongly dependent upon $p \mathrm{H}$ since only the deprotonated imidazole or $\mathrm{CN}^{-}$will coordinate to $\mathrm{Co}(\mathrm{III})$ and all ligand substitution reactions of $\mathrm{B}_{12}$ and alkyl aquo cobaloximes reported to date are second-order with rate-limiting addition of $\mathrm{L}$. The 
substitution of $\mathrm{H}_{2} \mathrm{O}$ proceeds through an unstable five-coordinate intermediate. Figure 7 shows the dependence of pseudo first-order rate constants for association and dissociation as functions of $p \mathrm{H}$ for both imidazole and cyanide.

\subsection{The mechanism of ligation reaction of $\mathrm{BrCH}_{2} \mathrm{Co}(\mathrm{DH})_{2} \mathrm{OH}_{2}$}

First-order kinetic dependence on incoming ligand concentration in ligation reactions is accounted for in each of the following detailed mechanistic schemes.

(1) $S N^{2}$ mechanism

$$
\mathrm{CH}_{2} \mathrm{BrCo}(\mathrm{DH})_{2} \mathrm{OH}_{2}+\mathrm{IMD} \rightleftarrows \mathrm{CH}_{2} \mathrm{BrCo}(\mathrm{DH})_{2} \mathrm{IMD}+\mathrm{H}_{2} \mathrm{O}
$$

(2) Outer-sphere complexation mechanism (equivalent to an $I_{d}$ process)

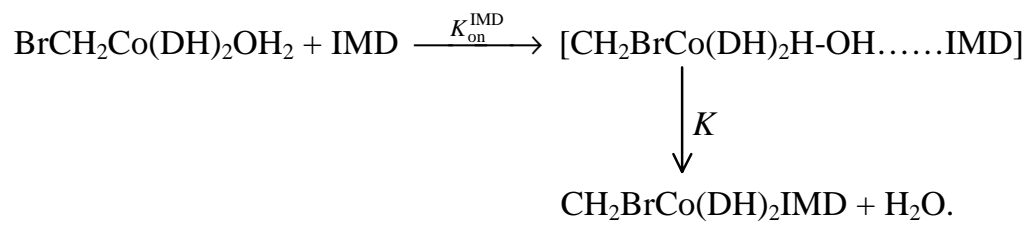

Plots of pseudo first-order rate constants $\left(k_{\mathrm{obs}}\right)$ against ligand concentrations are linear and not passed through the origin (figure 5). This indicates that there is a reversible reaction taking place and along with complex formation, some dissociation is also taking place. This is expected at low $p \mathrm{H}$ (below 7.0, IMD $p K_{a}$ is 7.241). Since the reactions are fast above $7.0 \mathrm{pH}$, it is not possible to study the reaction kinetics by conventional spectrophotometric techniques.

At low $p \mathrm{H}(4 \cdot 5)$ the graphs of $k_{\mathrm{obs}}$ against ligand concentration have non-zero ordinate intercepts at [ligand] $\rightarrow 0$, which indicates significant contributions from reverse rate constants $\left(k_{-f}\right)$. Values of $k_{-f}$ obtained from such plots or from independent measurements of $\mathrm{BrCH}_{2} \mathrm{Co}(\mathrm{DH})_{2} \mathrm{~L}$ dissociation were used to calculate the values of the apparent equilibrium constants.

The $p \mathrm{H}$ dependence of the apparent equilibrium constants for ligation, $K_{f}^{\text {app }}$, from $p \mathrm{H} 4.5$ to $8 \cdot 0$, is consistent indicating that the IMD free base is the sole ligating species. As the $p \mathrm{H}$ is decreased, $K^{\text {app }}$ decreases. The dependence of $p \mathrm{H}$ on the binding of imidazole to $\mathrm{RCo}(\mathrm{DH})_{2} \mathrm{OH}_{2}$ is seen in figure 3. This may be because of the competition of $\mathrm{H}^{+}$with $\mathrm{Co}(\mathrm{III})$ to bind with imidazole. Hence at lower $p \mathrm{H}$ most of the imidazole is protonated and not available for binding with cobalt. At higher $p \mathrm{H}$ imidazole (free base) available is maximum and binds to cobalt(III). Thus the $K_{f}^{\text {app }}$ is large at higher $p \mathrm{H}$. Above 8.0 or $9.0 \mathrm{pH} \mathrm{K} K_{f}^{\text {app }}$ is $p \mathrm{H}$ independent as after $8.0 \mathrm{pH}$ imidazole is completely free base and available for binding.

Comparison of $K_{\mathrm{IMD}}$ or $K_{\mathrm{CN}}$ of $\mathrm{CH}_{3}, \mathrm{C}_{2} \mathrm{H}_{5}$ and $\mathrm{BrCH}_{2}$ cobaloximes indicates that the order of $K_{\mathrm{IMD}}$ is $\mathrm{CH}_{2} \mathrm{Br}>\mathrm{CH}_{3}>\mathrm{C}_{2} \mathrm{H}_{5}$ (figure 2). As the electron-withdrawing capacity of the alkyl group trans to the water increases, it is difficult to displace water and with increasing electron-withdrawing power of the alkyl group, electron density on the cobalt decreases and $\mathrm{Co}(\mathrm{III})$ becomes a stronger Lewis acid and binds more strongly to the $\mathrm{N}$ donor ligand. This is proposed by Bresciani et $a l^{44}$. This is further supported by the 
association kinetics of the $\mathrm{BrCH}_{2}$ complex. In $\mathrm{CH}_{3}$ and $\mathrm{C}_{2} \mathrm{H}_{5}$ cobaloximes, imidazole or $\mathrm{CN}^{-}$bind to cobalt instantaneously, whereas in $\mathrm{BrCH}_{2}$ cobaloxime, IMD or $\mathrm{CN}^{-}$bind to $\mathrm{Co}(\mathrm{III})$ slowly. This is supported by the large $t^{1 / 2}$ of $\mathrm{BrCH}_{2} \mathrm{Co}(\mathrm{DH})_{2} \mathrm{IMD}$ complex, whereas it is difficult to measure rate constants for $\mathrm{CH}_{3}$ or $\mathrm{C}_{2} \mathrm{H}_{5}$ complexes by conventional spectrophotometry. The rate of displacement of pyridine in alkyl rhodoximes increases with increase in $\sigma$ donor power of the alkyl group ${ }^{44}$. Dependence of the equilibrium constants for ligation of bromomethyl cobaloximes by imidazole and cyanide up on the $p K_{a}$ values of the conjugate acids of the ligands indicates that the equilibrium constant of ligation of imidazole is smaller than that of the cyanide (table 1). This can be explained based on the stronger $\mathrm{Co} \rightarrow \mathrm{CN}^{-}$back bonding in the cyanide complex.

Soft (or class b) character has been assigned to alkyl cobaloximes ${ }^{45-47}$, vitamin $B_{12}$ and methyl cobalt corrins ${ }^{48}$. This is supported by the observed greater ligand affinity to $\mathrm{CH}_{3} \mathrm{Co}(\mathrm{DH})_{2} \mathrm{OH}_{2}$ of the soft thiolate anions as opposed to that of the hard primary amines ${ }^{49,50}$. In contrast, most of the $\mathrm{Co}(\mathrm{IIII})$ complexes, e.g. $\left[\mathrm{Co}\left(\mathrm{NH}_{3}\right)_{5} \mathrm{OH}_{2}\right]^{+3}$, are hard acids ${ }^{49}$ (with the interesting exceptions of the soft acids $\left[\mathrm{Co}(\mathrm{CN})_{5} \mathrm{H}_{2} \mathrm{O}\right]^{-2}$ and $\left.\left[\mathrm{Co}\left(\mathrm{NH}_{3}\right)_{5} \mathrm{SO}_{3}\right]^{+}\right)$. It appears that the presence of one or more soft or unsaturated ligands is sufficient to confer softness to a cobalt complex. Further, more softness appears to be directly related to the ability of a cobalt complex to stabilize a carbon-cobalt bond as seen in the cobaloximes, the cobalt corrins and even pentacyano $\mathrm{Co}(\mathrm{III})$. In the present study also, comparison of binding constants of $\mathrm{BrCH}_{2} \mathrm{Co}(\mathrm{DH})_{2} \mathrm{IMD}$ and $\left[\mathrm{BrCH}_{2} \mathrm{Co}(\mathrm{DH})_{2} \mathrm{CN}\right]^{-}$indicates that the higher stability of $\left[\mathrm{BrCH}_{2} \mathrm{Co}(\mathrm{DH})_{2} \mathrm{CN}\right]^{-}$is due to soft-soft interaction between $\mathrm{Co}(\mathrm{III})$ and $\mathrm{CN}^{-}$. Though both the ligands $\mathrm{CN}^{-}$and imidazole can form metal to ligand $\pi$ back-bonding, there is an enormous increase in the stability of the $\mathrm{CN}^{-}$complex compared to that of the IMD complex $\left[K_{\mathrm{CN}} / K_{\mathrm{IMD}}=27036\right]$. This can be attributed to the fact that IMD is a hard base whereas $\mathrm{CN}^{-}$is a soft base.

Table 2. First-order rate constants for the axial ligation of $\mathrm{BrCH}_{2} \mathrm{Co}(\mathrm{DH})_{2} \mathrm{OH}_{2}$ by L at $25 \cdot 0 \pm 0 \cdot 1^{\circ} \mathrm{C}$.

\begin{tabular}{|c|c|c|c|c|c|c|}
\hline $\begin{array}{l}\text { Conc. } \\
\text { (M) }\end{array}$ & $\begin{array}{l}k_{\mathrm{on}} \\
\left(\mathrm{s}^{-1}\right)\end{array}$ & $\begin{array}{c}k_{\|} \\
\left(\mathrm{dm}^{3} \mathrm{~mol}^{-1} \mathrm{~s}^{-1}\right)\end{array}$ & $p \mathrm{H}$ & $\begin{array}{l}k_{\mathrm{on}} \\
\left(\mathrm{s}^{-1}\right)\end{array}$ & $p \mathrm{H}$ & $\begin{array}{l}k_{\mathrm{off}} \\
\left(\mathrm{s}^{-1}\right)\end{array}$ \\
\hline \multicolumn{7}{|c|}{$L=$ imidazole } \\
\hline $\begin{array}{l}0 \cdot 012 \\
0 \cdot 019 \\
0 \cdot 025 \\
0 \cdot 031 \\
0 \cdot 038 \\
0 \cdot 044\end{array}$ & $\begin{array}{r}4 \times 10^{-4} \\
5.88 \times 10^{-4} \\
8.5 \times 10^{-4} \\
1.14 \times 10^{-3} \\
1.43 \times 10^{-3} \\
1.64 \times 10^{-3}\end{array}$ & $3.35 \times 10^{-3}$ & $\begin{array}{l}4 \cdot 5 \\
5 \cdot 0 \\
5 \cdot 5 \\
6 \cdot 0 \\
6 \cdot 5 \\
7 \cdot 0\end{array}$ & $\begin{array}{r}8.92 \times 10^{-4} \\
1.42 \times 10^{-4} \\
1.8 \times 10^{-3} \\
3.06 \times 10^{-3} \\
5.53 \times 10^{-3} \\
8.44 \times 10^{-3}\end{array}$ & $\begin{array}{l}1 \cdot 9 \\
2 \cdot 53 \\
3 \cdot 12 \\
3 \cdot 45 \\
3 \cdot 98\end{array}$ & $\begin{array}{r}2.79 \times 10^{-2} \\
1.4 \times 10^{-2} \\
2.5 \times 10^{-3} \\
9.0 \times 10^{-4} \\
8.32 \times 10^{-4}\end{array}$ \\
\hline \multicolumn{7}{|c|}{$L=$ cyanide } \\
\hline $\begin{array}{l}0 \cdot 012 \\
0 \cdot 019 \\
0 \cdot 025 \\
0 \cdot 031 \\
0 \cdot 038 \\
0 \cdot 044\end{array}$ & $\begin{array}{l}0 \cdot 016 \\
0 \cdot 0189 \\
0 \cdot 0256 \\
0 \cdot 0331 \\
0.0397 \\
0 \cdot 0438\end{array}$ & $0 \cdot 858$ & $\begin{array}{l}1 \cdot 95 \\
2 \cdot 13 \\
2 \cdot 5 \\
3 \cdot 1 \\
3 \cdot 47 \\
4 \cdot 0 \\
4 \cdot 5 \\
5 \cdot 0\end{array}$ & $\begin{array}{l}0 \cdot 0124 \\
0 \cdot 016 \\
0 \cdot 0247 \\
0 \cdot 025 \\
0 \cdot 0248 \\
0 \cdot 025 \\
0 \cdot 025 \\
0 \cdot 025\end{array}$ & $\begin{array}{l}0.08 \\
0.54 \\
1.2 \\
1.74\end{array}$ & $\begin{array}{l}0 \cdot 011 \\
0 \cdot 011 \\
0 \cdot 011 \\
0 \cdot 0105\end{array}$ \\
\hline
\end{tabular}


Rate constants are better correlated with the relative softness of the ligand among imidazole and $\mathrm{CN}^{-}$. At $p \mathrm{H} 4.5$ the rates of formation of imidazole complex is slow $\left[k_{\mathrm{obs}}=8.92 \times 10^{-4} \mathrm{~s}^{-1}\right]$, whereas the rate of formation of the $\mathrm{CN}^{-}$complex is fast $(2.5 \times$ $\left.10^{-2} \mathrm{~s}^{-1}\right)$. $\left[K_{\mathrm{obs}}^{\mathrm{CN}} / K_{\mathrm{obs}}^{\mathrm{IMD}}=28\right]$. $\left[\mathrm{BrCH}_{2} \mathrm{Co}(\mathrm{DH})_{2} \mathrm{CN}\right]^{-}$formation is 28 times faster than $\mathrm{BrCH}_{2} \mathrm{Co}(\mathrm{DH})_{2} \mathrm{IMD}$ (table 2). Even if we compare the dissociation rates, it tells that $\mathrm{CN}^{-}$ binds more strongly than imidazole. Bound $\mathrm{CN}^{-}$can be completely removed from cobalt $\left(k_{\mathrm{obs}}=0.011 \mathrm{~s}^{-1}\right)$ at $0 \mathrm{pH}$ whereas imidazole can be removed only at $1.9 \mathrm{pH}$ $\left(k_{\mathrm{obs}}=0.02792 \mathrm{~s}^{-1}\right)$.

\section{Conclusions}

Alkylcobaloximes of the type $\left[\mathrm{RCo}(\mathrm{DH})_{2} \mathrm{OH}_{2}\right]$, where $\mathrm{R}=\mathrm{CH}_{3}, \mathrm{C}_{2} \mathrm{H}_{5}$ or $\mathrm{BrCH}_{2}$ are prepared and their binding, association and dissociation rate constants with imidazole and cyanide are studied as functions of $p \mathrm{H}$. Association of these ligands with alkylcobaloximes are explained based on the HSAB principle.

\section{Acknowledgements}

We gratefully acknowledge the University Grants Commission, New Delhi for a fellowship to VS and financial support in the form of a project.

\section{References}

1. Pratt J M 1972 Inorganic chemistry of Vit $B_{12}$ (New York: Academic Press)

2. Schrauzer G N 1968 Acc. Chem. Res. 197

3. Ludwick L M and Brown T L 1969 J. Am. Chem. Soc. 915188

4. Brown T L, Ludwick L M and Stewart R S 1972 J. Am. Chem. Soc. 94384

5. Gustof R T and Brown T L 1973 Inorg. Chem. 122815

6. Brown K L, Chernoff D, Keliso D J and Kallen R G 1972 J. Am. Chem. Soc. 946697

7. Tauzher G, Dreol R, Gotta G and Green M 1973 J. Chem. Soc., Chem. Commun. 413

8. Crumbliss A L and Wilmarth W K 1970 J. Am. Chem. Soc. 922593

9. Trogler W C, Stewart R C and Marzilli L G 1974 J. Am. Chem. Soc. 963641

10. Covey W D and Brown T C 1973 Inorg. Chem. 122820

11. Pratt J M and Thorp R G 1966 J. Chem. Soc. 187

12. Randall W C and Alberty R A 1967 Biochemistry 61520

13. Thusios D 1971 J. Am. Chem. Soc. 932629

14. Schrauzer G N 1968 Acc. Chem. Res. 197

15. Brown K L and Kallen R G 1972 J. Am. Chem. Soc. 941894

16. Hamilton J A, Blakley R L, Looney F D and Winfield M E 1969 Biochem. Biophys. Acta 177 374.

17. Bay Stan J H, Looney F D, Pilbrow J R and Winfield M E 1970 Biochemistry 92164

18. Hamilton J A, Yamada R, Blakley R L, Hogen Kamp H P C, Looney I P and Winfield M E 1971 Biochemistry 10347

19. Yamada R, Tamao Y and Blakley R L 1971 Biochemistry 103959

20. Law P V, Brown G, Lien E L, Babior B M and Wood J M 1971 Biochemistry 103428

21. Pailes W H and Hogen Kamp H P C 1968 Biochemistry 74160

22. Hogen Kamp H P C and Holmes S 1970 Biochemistry 91886

23. Hill H A O, Pratt J M, Riordan M P O, Williams F R and Williams R J P 1971 J. Chem. Soc. A 1859

24. Babior B M 1970 J. Biol. Chem. 2456125

25. Essenberg M K, Frey P A and Abeles R H 1971 J. Am. Chem. Soc. 931242

26. Randaccio L C 1994 Chem. Acta 67235

27. Geremia S, Randaccio L, Dreos R and Tauzher G 1995 Chim. Ital. 12595 
28. Asaro F, Dreos R, Geremia S, Nardin G, Pellizer G, Randaccio L, Fauzher G and Vauno S 1977 J. Organomet. Chem. $\mathbf{5 4 8} 211$

29. Marques H M, Warden C, Monye M, Shangwe M S and Brown K L 1999 Inorg. Chem. 37 2578

30. Geremia S, Calligaris M and Randaccio L 1999 Eur. J. Inorg. Chem. 6981

31. Randaccio L, Geremia S, Zangrando E and Ebert C 1994 Inorg. Chem. 334641

32. Goutam Kumar P 1998 Indian J. Chem. A37 813

33. Brown K L and Satyanarayan S 1992 Inorg. Chem. 311366

34. Rajeshwar Rao A and Satyanarayan S 1998 Proc. Indian Acad. Sci. (Chem. Sci.) 11031

35. Rajeshwar Rao A, Sridhar V and Satyanarayan S 1999 Proc. Natl. Acad. Sci. (India) A69 23

36. Moore S J, Lachicotte R J, Sullivan S T and Marzilli L G 1999 Inorg. Chem. 38383

37. Brown K L and Satyanarayana S 1992 J. Am. Chem. Soc. 1145674

38. Moore S J, Lachicotte R J, Sullivan S T and Marzilli L G 1999 Inorg. Chem. 38383

39. Gupta B D, Qanungo K and Singh V S 1998 Indian J. Chem. A37 707

40. Brown K L, Lyles D, Pencovici M and Kallen R G 1975 J. Am. Chem. Soc. 97733

41. Brown K L and Awtrey A W 1978 Inorg. Chem. 17111

42. Brown K L 1979 Inorg. Chem. Acta 37 L513

43. Kallen R G 1971 J. Am. Chem. Soc. 936236

44. Bresciani P N, Dreos Garlatti R, Geremia S, Randaccio L, Tauzher G and Zangrando E 1990 Inorg. Chem. 293437

45. Crumbliss A L and Wilmarth W K 1970 J. Am. Chem. Soc. 922593

46. Hagve D N and Halpern J 1967 Inorg. Chem. 62059

47. Siang H G T and Wilmarth W K 1968 Inorg. Chem. 72535

48. Hill H A O, Pratt J M and Williams R J P 1969 Chem. Br. 5156

49. Basalo F and Pearson R G 1967 Mechanism of inorganic reaction 2nd edn (New York: Wiley) p. 23

50. Jencks W P 1969 Catalysis in chemistry and enzymology (New York: McGraw Hill) p. 89 